\title{
OVERVIEW OF HUMAN RIGHTS IN VENEZUELA ${ }^{1}$
}

ABSTRACT Formally constituted as a democracy, Venezuela has experienced a significant deterioration in the situation of human rights during the last decade. Such deterioration is partly due to an increasing concentration of power in the Executive branch which is reflected in the lack of independence of other branches of the State. The lack of independence - particularly in the judiciary and its subsidiary bodies - results in an increasing impunity in human rights related crimes. The present paper shows how the institutional framework has been dismantled and converted into a tool of a political project, with negative effects on human rights.

KEY WORDS Human rights, Venezuela, Hugo Chávez’s government.

\section{TOWARDS A NEW INSTITUTIONAL FRAMEWORK}

In December 1999, Venezuela approved a new Constitution which contains one of the most comprehensive catalogues of human rights, but at the same time has a rather weak institutional framework to ensure respect and realization of those rights. This design has been skillfully used by the government to progressively control almost all institutions. During the first 10 years, President Chávez launched a series of changes in the institutional structure whose most important milestone was the enactment of a new Constitution of 1999.

This article was submitted for publication before the death of Hugo Chávez. 
Responsibility for the process of concentration of power over the decade falls essential, but not exclusively, on the President. Other factors influenced the progressive and practically irreversible dissolution of the separation of powers upon which rests the rule of law, among them: (a) the interpretation promoted by the National Constituent Assembly - followed later by the National Assembly - to the effect that "representatives of society" referred to at the Constitution for the formation of the various nomination committees for selection of members of the Supreme Court, General Prosecutor, Electoral Council and so-called Citizen's Power, should include, in a majority, members of parliament; (b) the withdrawal of the opposition parties to participate in 2005 parliamentary elections; (c) the adoption of laws by ordinary process and by presidential decrees based on enabling legislation, contrary to a constitutional reform which was rejected; (d) redefinition of the polling by the Electoral Council for the 2010 parliamentary elections.

The opposition's decision not to participate in the parliamentary elections of 2005, led to the reconstitution of the legislative body totally dominated by Chávez supporters, thereby facilitating a new (lack of) balance of power, as legislators are primarily responsible for the appointments of the top positions of the other branches of State powers. However, lack of independence of legislative, judicial, electoral and so-called citizen's power from the executive branch does not only come from the appointment of members clearly associated with the ruling party, but also from direct interference with their functions.

In December 2009, the President of the Supreme Court expressed: We cannot keep thinking about the separation of powers because it is a principle that weakens the state. ${ }^{2}$ Similarly, the President of the National Assembly has repeatedly stated that the role of Parliament is to produce revolutionary laws demanded by President Chávez. ${ }^{3}$ On the other hand, the President himself frequently instructs parliamentarians and the President of the Supreme Court, as well as the General Prosecutor to act according to his will.

Once control of all branches of Public Power by the Executive was secured, the second stage was to control social organizations. A first test of strength was the closure of RCTV, one of the largest television stations in May 2007. General repudiation of the closure of the television station led to the first electoral defeat of Chávez, when a comprehensive reform of the Constitution was rejected by a referendum in December of that year.

2 L.E. Morales, 'La division de poderes debilita al Estado', El Nacional (Caracas), 5 December 2009, at <http://www.el-nacional.com/www/site/p_contenido.php?q=nodo/111866/Nacional/Luisa-Estela-Morales:-La-divisi\%C3\%B3n-de-poderes-debilita-al-Estado>,19 April 2010 or L.E. Morales, 'La división de poderes debilita al Estado', at <http://www.eluniversal.com/2009/12/05/pol_art_morales:-la-divisio_1683109.shtml>, 17 June 2013 [The link of "El Nacional" seems to be broken. Original capture date was 19 April 2010. There is another link (El Universal) that is still active. I include it in case you prefer to use an active one]

3 See, for example, a statement on February 21, 2010 by the President of the National Assembly: We want an Assembly to support the revolution. C. Flores, 'Queremos una Asamblea para el soporte de la revolución', at <http://www.el-nacional.com/www/site/p_contenido.php?q=nodo/123846//Cilia-Flores:-Queremos-una-Asamblea-para-el-soporte-de-la-revoluci\%C3\%B3n>, 19 April 2010. 
Although between 2006 and 2009 there were several attempts to secure greater control over the activities of civil society organizations, it was only in 2010 after losing the majority of the Parliament, when there was a sharp acceleration of this process control. Thus, in the second half of 2010, occurs which could be described as a progressive statization of social life, characterized by controlling, via legislation and de facto, media, business sector, universities, NGOs and political parties by the approval of 39 laws to regulate, in a restrictive, ambiguous, and hegemonic way, various spheres of social life. ${ }^{4}$

\section{INDEPENDENCE OF THE JUDICIARY}

Human rights face serious obstacles due to the lack of independence among powers. Stability of judges has always been an issue in Venezuela, as it was noticed in Provea's first annual report in $1989 .{ }^{5}$ For some years, there was a trend to increase the number of career judges. This trend was seriously reverted after 1999 when the Constitutional Assembly decided to declare "judicial emergency". Since then the number of career judges dropped to $10 \%{ }^{6}$ Lack of stability, together with discretional hiring of lawyers to become part of the judicial system, has developed into key factors to understand the problems affecting the administration of justice.

A Report released by the Inter-American Commission for Human Rights (IACHR) in $2010^{7}$ mentions a wide range of issues affecting independence of the judiciary: regularization of the situation of judges appointed without an open public competition, failure to hold open public competitions for appointing public prosecutors, lack of stability of judges and prosecutors in their positions, provisions that allow for broad subjectivity in the removal and indefinite suspension of judicial officers, disciplinary bodies' lack of independence and impartiality, provisional status of judges and prosecutors, among others.

A recent study shows that the jurisdiction in charge of ruling on cases against the administration (Contencioso - Administrativo) avoids making decisions on the sub-

4 Among the laws approved is an amendment to the Law on social responsibility of radio and TV, a reform of the Organic Law on Science, Technology and Innovation; the Law for the Defense of National Sovereignty and Self-Determination, an amendment to the Law on Political Parties, Public Meetings and Demonstrations; amendment to the regulations of debates of the National Assembly; a reform of the Organic Law of Telecommunications. Also passed a new law on universities, which was subsequently vetoed by the President as it found great resistance of the student movement and the academic sector, but some of its provisions have been applied in practice. Also a set of laws aimed at the creation of "Communal State was adopted".

5 Situación de los Derechos Humanos en Venezuela, Informe Anual octubre 1988/ Septiembre 1989, Programa Venezolano de Educación - Acción en Derechos Humanos (PROVEA), Caracas 1989.

6 By 1998-99 approximately $80 \%$ of judges did not have tenure. As part of the judicial reform process (World Bank project) this trend was reverted and more than $50 \%$ of judges had a permanent appointment. By $200190 \%$ of judges had a provisional designation; this trend has not been reverted during the last decade.

7 Inter-American Commission on Human Rights, Democracy and human rights in Venezuela, OEA/ Ser.L/V/II. Doc. 54. Washington, D.C., 30 December 2009. 
stance of the matter; its rulings tend to be limited to formalities. In 2005, for example, only $2.9 \%$ of cases sentenced, dealt with the substance of the controversy. ${ }^{8}$ It is worth mentioning that in October 2003, three of the five Magistrates of the First Court of Administrative Disputes were dismissed for alleged "inexcusable miscarriage of justice" in a case against the Central Administration. It is easy to understand why incoming Magistrates avoid dealing with the substantive aspects of controversies against the administration. These three Magistrates were dismissed without any administrative or disciplinary procedure. The case was presented by the IACHR before the Inter-American Court which ruled in favor of the Magistrates.' However, the Supreme Court decided that the Inter-American Court ruling was "unenforceable". This was the first case where the Supreme Court openly disregarded an Inter-American Court ruling.

On December 10, 2009, María Lourdes Afiuni, a tenure Judge since 2006, conducted a hearing in the case against a defendant, who at the moment had been in preventive detention without trial for more than 2 years. ${ }^{10}$ During the hearing the defense reiterated the petition for conditional release and Judge Afiuni decided to substitute the preventive detention for a conditional release pending trial, imposing him other restrictions. The judge based her decision on the Venezuelan Criminal Code, and on a recommendation made by the UN Working Group on Arbitrary Detention with regard to the defendant. ${ }^{11}$ Less than a hour after judge Afiuni took her decision, a group of policemen from the Department of Intelligence (Servicios Bolivarianos de Inteligencia, SEBIN), arrested Judge Afiuni and two Bailiffs without a warrant at her Court. On December 11, President Chávez accused Judge Afiuni calling her a "bandit" and asking a penalty of 30 years in prison during a simultaneous national TV and radio broadcast; the General Prosecutor attended the event. On the same day the General Prosecutor's Office presented Judge Afiuni before a criminal tribunal on charges of corruption, abuse of authority, favoring for evasion and racketeering, setting as a place of detention for Judge Afiuni the National Institute of Feminine Orientation (acronyms in Spanish INOF). At the INOF prison there are 24 women inmates who Judge Afiuni had sentenced to prison during her work, including her next door inmate. While in prison, Judge Afiuni was subjected to several death threats and harassment. Due to harsh prison conditions Judge Afiuni suffered from different health conditions. On February 2nd, 2011, the tribunal in charge of the, agreed to change her place of detention from INOF to house arrest. The measure became effective once she was discharged from hospital where she was sent for surgery. At the time of preparing this paper, the judge

A. Canova González, La realidad del contencioso administrativo en Venezuela, Caracas 2009.

Case of Apitz Barbera et al. ("First Court of Administrative Disputes") v. Venezuela, Inter-American Court on Human Rights, Judgment of 5 August 2008. Series C № 182.

10 At the time of the decision of judge Afiuni, the defendant had spent 2 years and 10 months in prison. The maximum period of preventive detention referred in the Code of Criminal Procedure is 2 years.

11 UN Human Rights Council, 'Opinions adopted by the Working Group on Arbitrary Detention', 2 March 2010, ‘OPINION № 10/2009', p. 307, at <http://www2.ohchr.org/english/bodies/hrcouncil/docs/13session/A-HRC-13-30-Add1.pdf >. 
remains arbitrarily deprived of her liberty without trial. The State has ignored all requests from international and regional bodies for the protection of human rights calling for her immediate and unconditional release. ${ }^{12}$

Afiuni's case is unique and emblematic, not only for being a judge arbitrarily imprisoned for doing her work, based on a decision of a UN human rights mechanism, but by what is known in Venezuela as the "Afiuni effect". No judge dares today to agree to a prisoner's parole if he or she finds that the decision may be contrary to the wishes of the authorities. As a consequence, prison population has almost doubled since late 2009.

\section{THE NEW INSTITUTIONAL FRAMEWORK AND ITS IMPACT ON HUMAN RIGHTS}

Although human rights might and are violated everywhere, a key element to redress victims in a democratic society is the presence of checks and balances. The lack of division of powers in Venezuela puts civil society in general and victims in particular, in a helpless position.

\section{A. The right to political participation}

The right to participation is widely enshrined in the Constitution of the Bolivarian Republic of Venezuela, from the preamble to the final article 350. However, this right has been violated in different ways.

\section{i. Lack of acknowledgment of popular will}

While the executive authorities have formally recognized the results of elections that have been adverse, in practice people's will is not acknowledged. Whenever the majority decision has been contrary to the government, parallel mechanisms have been developed to ensure a hegemonic control of power over all institutions.

In 2007 the President proposed a package of reforms to the Constitution, which was submitted for consultation through a referendum which resulted in the rejection of $51 \%$ of voters who participated. Even though the reform was defeated, most of the laws pub-

12 Inter-American Commission on Human Rights, 'Precautionary Measures Granted by the Commission during 2010', PM 380-09 - María Lourdes Afiuni, Venezuela, at <http://www.cidh.oas.org/medidas/2010.eng.htm>, 20 January 2010; 'UN experts: President Chávez deals new blow to independence of judges and lawyers in Venezuela', United Nation Press Release, 16 December 2009, at <http://www. ohchr.org/EN/NewsEvents/Pages/DisplayNews.aspx?NewsID=9677\&LangID=E>, 16 December 2009; Inter-American Court for Human Rights, 'Precautionary Measures IACHR', Res 10 December 2010, at <http://www.ucab.edu.ve/tl_files/CDH/Maria\%20Lourdes\%20Afiuni/MedidasCorte.pdf>; 'UN experts alarmed at continued detention of Venezuelan Judge Afiuni', United Nation Press Release, 27 December 2011, at <http://www.ohchr.org/EN/NewsEvents/Pages/DisplayNews.aspx?NewsI$\mathrm{D}=11745$ \&LangID=E $>, 27$ December 2009. 
lished on July 31 st 2008, under special powers granted to the President of the Republic, contain provisions that violate the Constitution whose reform was rejected. ${ }^{13}$

In November of 2008 the election of governors and mayors was held. Immediately a series of decisions were taken, through a legislative or administrative way, in order to reduce powers and regional and local budgets, being the governors and mayors of the coalition of parties in opposition to the Government the most affected. The Special Law on the Organization and Regime of the Capital District adopted in April of 2009 created the role of the Head of Government of the Capital District, taking functions, resources and infrastructure to the new headquarters, which is headed by a person directly appointed by the President, on the fringes of popular election. In addition, resources and responsibilities that traditionally belonged to the governors or mayors were reduced or transferred to the National Executive. In July of 2009 affected Governors, as well as the Major of the Metropolitan District of Caracas, went the Organization of American States where they submitted documentation to the Secretary-General and the Inter-American Commission on Human Rights on the limitations imposed by the Executive on the exercise of their mandate. ${ }^{14}$

In September of 2010, a new election of members of the Parliament took place. The results implied the loss of the $2 / 3$ and $3 / 5$ parts of seats required to maintain the parliamentary majorities required to make certain decisions. Immediately, the outgoing Parliament streamlined the approval of a series of laws, proceeded to appoint 9 judges and 32 alternates of the Supreme Court of Justice, approved a new internal regulation that limits the parliamentary management, and passed a new enabling law to the President for a period of 18 months.

Although in theory the motivation to adopt a new enabling law for the President was to address the effects of heavy rains in November 2011, the law gave him broad powers to legislate on various subjects. ${ }^{15}$ Additionally, the President was far beyond any power delegated by Parliament, covering subjects that are part of the "legal reserve", such as the creation of offenses and the involvement of human rights which, according to the Constitution, can only be addressed by the legislature. ${ }^{16}$

Meanwhile, the Supreme Court of Justice, through a decision that contradicted the Constitution, rejected the parliamentary immunity to two members of the Parliament

13 A total of 26 laws were dictated by decree by the President on July 31, 2008, the last day of the Enabling Act.

14 The Inter-American Commission on Human Rights, in its report Democracy and Human Rights in Venezuela reflects this situation in the section "Modification of the powers of elected officials" (paragraphs 74 et seq.).

15 In addition to matters directly related to rainfall and other natural disasters, the National Assembly authorized the President to legislate in areas such as infrastructure, transportation, utilities, telecommunications and information technology, planning, comprehensive development, use of urban land and rural areas, finances and taxation, public safety and legal security, national defense, international cooperation and socio-economic system of the Nation. A total of 35 laws were dictated by the President under this Enabling Act.

16 The reform of the Banking Act creates offenses; the reform of labor law affects the rights of workers and the new Criminal Procedure Code creates offenses, modifies penalties and affects human rights in the areas of due process, rights of inmates and prison conditions. 
who, upon being elected, were facing a process before the national courts. One of them underwent a summary trial, where a male "witness" was summoned to appear and was presented with a woman's name, his face covered with a hood. The elected deputy was sentenced to 19 years in prison.

\section{ii. Persecution of dissent and restrictions on political participation to the political and social organizations}

In 2003 took place a process of collecting signatures to convene a consultation on the revocation of the President's term. The President of the National Electoral Council, on instructions from the President of the Republic ${ }^{17}$, gave a copy of the list of signatories to the then National Assembly member (Diputado) Luis Tascón, who made it public on a web site; it is known as "Tascón list". In April 2005, the President ordered "bury" the Tascón list, but it is still being used by the government as a tool of discrimination towards those who signed in 2004, in areas such as jobs in public administration, scholarships and study quotas, contracts with the public administration, among others. ${ }^{18}$ Human rights organizations have documented evidence that the list remains active and continues to be used as a tool of discrimination. ${ }^{19}$

On February 12, 2012, primary elections were held by the opposition to the nominations for President of the Republic, as well as some governors and mayors. The Bureau of Democratic Unity (acronym for Mesa de Unidad Democrática, MUD), in charge of the process, anticipated conditions that would ensure the secrecy of the voter turnout in order to avoid repetition of events of persecution as developed because of the "Tascón List". Among those conditions was the use of optional (not mandatory) indelible ink which is customarily used to mark the little finger of the voter, not using fingerprints readers and safe preservation and subsequent destruction of the electoral rolls once the process was completed.

The day after the primary elections, a candidate who came fourth for a mayoral bid filed an amparo writ before the Supreme Court. On February 14, the Supreme Court ordered the surrender of "all" the books used in the election to the armed forces. ${ }^{20}$

17 A facsimile of the letter from the President of the Republic to the President of the National Electoral Council can be seen on the web site: at <http://www.noolvidaremos.com/news/lista-de-tascon-aplicacion-maisanta/>, 11 March 2011; There are also detailed explanations on the use of the list: A. Boyd, 'Lista De Tascon: Maisanta Software Explained', at <http://vcrisis.com/index. php?content=pr/200512061532>, 11 March 2011.

18 Between 2004 and 2005, the Human Rights Center, Andres Bello Catholic University attended several discrimination cases for having signed the request for consultation to the revocation of the presidential term. Cases were not successful in national bodies and one of them was elevated to the Inter-American Commission on Human Rights. A study was published in 2009 'The price of political opposition: Evidences from Venezuela's Maisanta', which can be consulted at: <http://frrodriguez. web.wesleyan.edu/docs/working_papers/maisanta_april2009_final.pdf >.

19 There is currently a large number of pages on the internet from which the list can be downloaded.

20 Supreme Court. Constitutional Chamber. Decision № 12-0219, 14 February 2012. On line version available at: <http://www.tsj.gov.ve/decisiones/scon/Febrero/66-14212-2012-12-0219.html>, 15 February 2012. 
The news on the possible delivery of the electoral rolls immediately aroused serious concerns in the population, due to the possibility of violation of the confidentiality of participation in the consultation, as had secured the MUD. Those responsible for the safekeeping of the books, both in Venezuela and around the world proceeded to burn them, which resulted in punishment of a fine against the President of the MUD's Electoral Commission. ${ }^{21}$ What is significant about this immediate and spontaneous mobilization of civil disobedience is that it came as a reaction to what could become a new "Tascón list", showing that the fear of using discriminatory mechanisms remains in the collective spirit.

In December, 2010, the outgoing Parliament, adopted the Law of Defense of the Political Sovereignty and Self National Determination. ${ }^{22}$ This law restricts the action of "organizations for the defense of political rights". ${ }^{23}$ The breadth of the definition involves regular activities that constitute the core action of the majority of civil organizations, including human rights organizations, such as the monitoring the Administration's performance.

One of the main constraints referred to in the Law is the prohibition and punishment to receive funding from foreign entities. It should be noted that in Venezuela, political parties already are prevented from receiving external founding; however the scope of the law seems to be directed to organizations other than these, such as civil organizations, including those defending human rights.

Among the sanctions established by the law there are fines for large sums unmanageable for most organizations; political ban of its directors and even custodial measures against them, considering that penalties contained in other laws could be applied. Opinions given by foreign guests are equally punished when they are deemed offensive by the institutions of the State, which is expected to have inhibitory effects.

\section{iii. Political persecution and the right to fair trial}

Nearly 40 people remain in prison or under house arrest on political grounds and many others are facing trial, or have been sentenced. Although government spokespersons state that there are not political prisoners but politicians in prison, almost all cases present similar patterns:

21 Supreme Court. Constitutional Chamber. Decision № 145, 23 February 2012. On line version available at: <http://www.tsj.gov.ve/decisiones/scon/Febrero/145-23212-2012-12-0219.html>, 28 May 2012.

22 The full text of this law can be searched in Gaceta Oficial, 23 December 2010, at <http://www.tsj.gov. ve/gaceta_ext/Diciembre/23122010/E-23122010-3043.pdf\#page=1>, 6 March 2010.

23 The Act defines Organizations with political purposes: those involved in public or private activities to promote the participation of citizens in public spaces, exercise control over the public authorities or promoting candidates who aspire to hold public office of popular choice. And organizations for the defense of political rights: those which have as their purpose in its constitution promote, disclose, report, or defend the full exercise of the rights of political citizenship. 
- The length of trials is extremely long. ${ }^{24}$

- Most appeals and other judicial recourses are systematically rejected.

- Criminal charges are "inflated" as a way to keep prosecuted in prison. ${ }^{25}$

- Corruption charges are often manipulated for political purposes.

- Evidences favoring defendants are frequently disregarded.

- In sum, the right to fair trial is seriously threatened.

In addition, a mechanism used in recent years to limit opportunities of opposition candidates to run for public office (state and local governments as well as parliament) is the restriction through administrative resolutions. According to the law, such restriction ("inhabilitación") can only be applied as an accessory penalty in criminal trials after final sentence has been decided.

Some 400 people had their political rights restricted by administrative measures prior to regional elections of November 2008. As indicated by the Inter-American Commission on Human Rights, a great majority of the disqualified persons belonged to the political opposition. ${ }^{26}$ At least seven candidates to the National Assembly were subjected to such restrictions for congressional elections due to take place in September 2010.

\section{B. Freedom of expression}

The Venezuelan government has made continuous attempts to reduce the influence of independent journalism. Some of the patterns in this area are:

- Closure of media critical to the government. ${ }^{27}$

- Confiscation of equipments. ${ }^{28}$

- Withdrawing broadcasting permissions to 34 radio stations. ${ }^{29}$

24 According to the Penal Procedures Code, defendants should be brought to preliminary hearing 10 days after the General prosecutor's Office has presented charges; in practice, the length of time between both steps in political cases varies from 4 month to more than one year.

25 According to the Penal Procedures Code, the general rule is that persons should be judged without restrictions to their personal freedom; some coercive measures might be requested by the General Prosecutor's Office. However, imprisonment is an exceptional measure that only applies for serious offenses that imply sentences of more than 10 years imprisonment in its maximum limit. On the other hand, some defendants facing trial for political motivations are accused for crimes of less than 10 years in prison; however, courts refuse their release during the process. In any case, imprisonment during trial cannot exceed 2 years, but most political prisoners remain in prison after that term. Inter-American Commission on Human Rights, Democracy and Human Rights in Venezuela, p. 11.

27 RCTV broadcasting permission for open TV was not renewed in May 2007 and most of its equipments were confiscated. In early 2010 the government requested cable operators to withdraw RCTV from their cable service.

28 In addition to RCTV, Globovisión microwave transmission system was confiscated in December 2003.

29 The decision was implemented in August 2009. CONATEL had previously announced that broadcasting permissions will be revoked to more than 240 radio stations. Hence, the threat remains and as a consequence, some radio stations have applied self-censorship. 
- Short-term detention of journalists and photographers, with confiscation and or destruction of filming or photographic materials. ${ }^{30}$

- Penal prosecution of at least one journalist who spent eight and a half month in prison and was sentenced to three and a half years in jail for alleged corruption charges in a case condemned by the Inter-American system as well as international NGOs. ${ }^{31}$

- Official pressure to advertising companies to withdraw publicity from media critical to the government. ${ }^{32}$

- Disciplinary, administrative and criminal procedures against media, media owners and journalists. ${ }^{33}$

- Attacks with fire weapons and explosives to the headquarters of media and journalists houses by civilian groups close to the government; investigation of most of these cases remain unfinished despite the open recognition of authors. ${ }^{34}$

A large number of these cases have been presented to the judiciary. When decisions have been taken, they have always been against the media.

The right to freedom of expression also includes the right to seek information. Journalists and media critics to the government often are not invited or are prohibited access to press briefings by public entities. Government spokespersons refuse to give statements to the media and it is difficult to have access to information and statistics on public issues such as health, education, employment and housing. In 2004 the press office of the Judicial Police was closed down; this constitutes a serious obstacle on a sensitive issue for the Venezuelan society, since criminal violence is considered one of the highest in the region.

In March of 2005, the criminal code was amended to extend penalties and incorporate other public personnel subject of protection of their honor and reputation ${ }^{35}$.The

30 For detailed information see: Inter-American Commission on Human Rights, Democracy and Human Rights in Venezuela.

31 The case of journalist Gustavo Azócar is documented at Inter-American Commission on Human Rights: Democracy and Human Rights in Venezuela.

32 Venezuela state-owned cell phone company, Movilnet, conditioned the advertising support of "Research in Motion" (RIM) from Canada, to the musical "Jesus Christ Superstar" - even with RIM's own founds in critical media such as Globovisión (TV), El Nacional, El Universal, Tal Cual, El Nuevo País (newspapers), Ateneo FM (radio) and Zeta Magazine. The terms of the agreement had been directly approved in an exchange of communications between "Palo de Agua" (local producer of the musical), Movilnet and RIM. This conditionality took place on 28 January 2010, in a meeting with managers of RIM and Movilnet; Movilnet offered more resources if the exclusion of the above-mentioned media was accepted.

33 This situation is documented at Inter-American Commission on Human Rights: Democracy and Human Rights in Venezuela.

34 The IACHR 2009 Report states that "Movimiento Tupamaro, Colectivo La Piedrita, Colectivo Alexis Vive, Unidad Popular Venezolana, and Grupo Carapaica have been acting with the encouragement and acquiescence of the Venezuelan State". Inter-American Commission on Human Rights, Democracy and Human Rights in Venezuela, p. 205.

35 Before the reform, the standard had a scope for the President of the Republic, the Executive Vice President, Government Ministers, Governors, the Major of the Metropolitan District of Caracas, 
reform of the Criminal Procedure Code ${ }^{36}$ strengthens the regression in the content and guarantee of the right to freedom of expression and information, ratifies and deepens the contempt or vilification against public officials, increases the discretion of judges to decide whether a conduct or expression falls within the respective criminal type, and is discriminatory to differentiate the officer with respect to the person, limiting citizens' control over public management.

Limiting access to public information also affects civil society organizations. The Inter-American Commission on Human Rights (IACHR) documented those referring to the work of monitoring the human rights organizations..$^{37}$ In a study based on the follow-up on 157 requests of information ${ }^{38}$ to 50 public institutions between February and March of 2008, more than $70 \%$ of the agencies did not reply, by refusal or administrative silence, and only $10 \%$ of the answers were appropriate. ${ }^{39}$

In 2010 restrictive standards were adopted affecting the right of access to information such as the Presidential Decree number 7.454, which ordered the creation of the Centre of Situational Survey of the Nation (CESNA), as a decentralized body of the Ministry of Popular Power for the Interior and Justice. Article 9 empowers the President of the CESNA to declare the nature of reserved, classified or of limited disclosure of any information, without expressly establishing in what cases or circumstances the officer is empowered to declared the reserved nature of the information. The limitation on the right was not established by the law in a formal sense, but rather through a Presidential Decree in violation of article 325 of the Constitution.

\section{Right to peaceful protest}

In December 2002, the National Assembly approved the Organic Law on National Security. Article 56 provides for prison sentences of five to ten years for those who organize, hold or abets the activities within the security zones affecting the organization and operation of military facilities, utilities and basic industries, economic or social life of the country. Previously, in September 2002, the so called security zones had been established by presidential decree covering a wide range of areas. The director of the

the judges of the Supreme Court, the Presidents of the Legislative Councils and senior judges, to initiate criminal proceedings for the offence of contempt. Legal reform joined the members of the Parliament, officials of the National Electoral Council, the Attorney General, to the Ombudsman, the Comptroller-General and the members of the military high commander

36 Criminal Code of Venezuela. Official Gazette № 5768E, August 13th 2005, at <http://www.fiscalia. gov.ve/leyes/6-CODIGOPENAL.pdf>.

37 Comisión Interamericana de Derechos Humanos, 'Democracia y derechos humanos en Venezuela', 30 December 2009, paragraphs 647 to 663, at <http://www.cidh.org/countryrep/Venezuela2009sp/ VE09CAPVSP.htm\#V.B>.

38 Venezuelan constitutional rule enshrines the right of petition and through this resource it can be made requests for information to the public bodies.

39 'Espacio Público: Acceso a la información pública en Venezuela', Caracas 2008, at <http://espaciopublico.org/index.php/Biblioteca/doc_download/250-Acceso-a-la-Informacion-publica-en-Venezuela$-2008>$. 
NGO Control Ciudadano (Citizen Watch) estimates that 34\% of the country is considered security zone. ${ }^{40}$

According to Provea and Espacio Público, peaceful protest had almost doubled between 2006 and 2009 and so has repression ${ }^{41}$. As of November 2009, Provea registered 2.240 persons who face criminal charges for participating in demonstrations. The majority are workers, trade union leaders, students and social leaders. Emblematic cases include:

- 1507 peasants under presentation to courts (according to Jira Jara Movement).

- 25 steel workers (SIDOR) under presentation to courts since 2006. One of them sentenced to seven years in prison in 2011 and subsequently subjected to probation, awaiting a second trial in August 2012.

- 27 PDVSA workers (oil industry).

- 11 workers of the metropolitan mayor's office.

It is interesting to note that half of workers and trade union leaders facing criminal charges for demonstrations are sympathizer or supporters of President Chávez. They are generally charged for resistance to authority, carrying and undue use of fire arms, blocking public roads/streets, instigation to commit an offense/crime, damage/stealing at shops, "agavillamiento" (illegal association), disturbing public order and breaking into security zones. In one year, three students, two worker and a homeless were killed in demonstrations. ${ }^{42}$

Finally, it should be noted that Venezuelan legislation requires organizers of demonstrations to "give notice" of the location or itinerary and time of demonstrations. However, government authorities have interpreted "notification" as similar to "permission" or "authorization". The IACHR notes that [it] has been informed of the existence of discrimination at the moment of granting permits, in that groups that demonstrate in favor of government policies receive authorization to demonstrate in locations in which groups that protest against the government are not authorized to demonstrate. In this respect, the Commission was informed that those who are against the government are not allowed at the Miraflores Palace, the seat of the Venezuelan government. ${ }^{43}$

The student's movement has been particularly affected by this discriminatory practice.

\section{Right to property}

According to Observatorio de la Propiedad (Property Watch) there have been 3.355 actions against private property between 2005 and 2011, out of which 915 are expropria-

40 Interview to Rocío San Miguel Correo del Caroní, available at <http://informe21.com/rocio-san-miguel/rocio-san-miguel-\%E2\%80\%9Caqui-hay-politica-acelerada-discriminacion\%E2\%80\%9D>.

41 Information provided by human rights NGOs Provea and Espacio Público to the Inter-American Commission for Human Rights. Hearing on Judicialization of Social Protest. 137th Regular Session, 2 November 2009.

42 Fatal victims are: Douglas Rojas Jiménez (10.07.08) Student, Gabriel Marcano Hurtado y Pedro Suárez (29.01.09) Workers, José Gregorio Hernández (20.03.09) Homeless, Yuban Ortega (01.05.09) Student, Jesús Eduardo Bello (08.12.09) Student.

43 Democracy and Human Rights in Venezuela, p. 34. 
tion of industries and business; 1.911 are considered "land reclamation" (70\% of whom were not large estates), and 529 are invasions. ${ }^{44}$ This includes a wide range of areas such as: farms and land (agriculture or cattle), urban land, buildings (housing), universities, cultural centers, industry, oil, mining, cement, energy (electricity), media and telecommunications, commerce, shopping centers, hotels and tourism (cable car), warehouses, wholesalers and banks.

According to the law expropriations can only be declared by courts and compensation should be determined. However, in a large number of cases expropriations have been declared by an administrative act, and compensations are unilaterally decided and paid with extreme delay, if ever. Only expropriations involving multinational corporations have received compensations; no cases of expropriations against national owners have ended in compensation according to the law. A recent trend shows that expropriations are being used as a sanction against alleged violations to administrative or economic regulations, in some cases based on political motivations. ${ }^{45}$

The study concludes that This concentration of economic power in the hands of the State, causes a series of structural damage, both the social, economic and cultural areas as well as being a disincentive to national and foreign private investment in the country. ${ }^{46}$

\section{E. Persecution of social and human rights movement}

Human rights defenders are frequently subject to harassment, disqualification, threats and criminalization, either in public statements by governmental spokespersons or through direct action. ${ }^{47}$ At least six defenders or groups of defenders have been granted protection measures by the Inter-American Commission or the Inter American Court on Human Rights. At least two human rights defenders and seven members of a family group have been killed by the State Police of Aragua since 1998; the last assassination took place in May 2011, in spite the fact that the Inter-American Court on Human Rights had agreed precautionary protection measures for the family group in September 2004. ${ }^{48}$

As part of investigations around the Coup attempt of April 2002, a document issued by the National Assembly mentioned a number of entities allegedly cooperating with the objectives of the Empire:

Inter-American Press Association (IAPA), Human Rights Watch (HRW), right-wing parties in the European Parliament and the Mercosur Parliament, the U.S.

44 'Observatorio de la propiedad (Property Watch)', at <http://cedice.org.ve/?p=6244>, 2 June 2012.

45 For a comprehensive study on this issue see A. Canova González, L.A. Herrera Orellana, K. Anzola Spadaro, ¿Expropiaciones o vias de hecho? La degradación continuada del derecho fundamental de propiedad en la Venezuela actual, Caracas 2009, p. 156.

46 Ibid., p. 239.

47 A detailed account of actions against human rights defenders can be seen in: Democracy and Human Rights in Venezuela, pp. 159-173.

48 Precautionary Measures Eloisa Barrios and her family: Inter-American Commission on Human Rights, 'Precautionary Measures 2004', at <http://www.cidh.org/medidas/2004.eng.htm>, 2 March 2012. 
Treasury Department, the Christian Democrat International and Christian Democratic Organization of America (ODCA), the so-called Anti-Drug Czar of the United States, the FBI, CIA, MOSAD and their agents in various intelligence organizations around the world, The Rendon Group, the television networks CNN, ABC News, Televisa, Univision, FOX, CBS, TV Azteca, TV Globo, the Prisa group and print media controlled by the elite in countries subordinate to U.S. interests, the Inter-American Commission on Human Rights (IACHR), the International Republican Institute (IRI) ${ }^{4}$.

International NGOs and other cooperation agencies have been subject to disqualifications and attacks, being the most noticeable the expulsion of Human Rights Watch's Executive Director, José Miguel Vivanco, in September 2008 under arguments of "interference with internal affairs", a very frequent argument used to avoid international scrutiny on the human rights situation in Venezuela.

In an attempt to restrict international support to local NGOs, including human rights organizations, a draft law has been introduced to the National Assembly to regulate international cooperation. The language of the draft is extremely vague, opening the door for discretionary interpretation.

Although the law of international cooperation has not been approved there have been a number of episodes in which the government has gradually begun to limit the ability of action of independent organizations. Notary offices have refused to register the bylaws of organizations including terms of its objectives as "human rights", "democracy" or "participation". Some 20 human rights organizations are under investigation by the General Prosecutor's Office since mid 2010 based on the foreign origin of their funding sources. In early 2012, the Comptroller Committee of the National Assembly launched an investigation against three other organizations, although that Commission only has jurisdiction to investigate public institutions. More recently, the new Criminal Procedure Code approved by presidential decree, in an unconstitutional extension of the powers conferred by the Enabling Act, excluded human rights organizations as legitimated to file lawsuit on behalf of victims of human rights violations.

On the other hand, the package of laws passed in December 2010 points to a displacement of independent social and human rights organizations. The cornerstone of this process of takeover of civil society - and the resulting medium-term neutralization of independent organizations- is the Organic Law of People's Power, which regulates public participation. This law determines the recognition of organizations depending on their articulation with an instance of the People's Power, duly recognized by the Law and registered with the Ministry competent in terms of citizen participation ${ }^{50}$.

Thus, as it has been characterized by Civilis:

Contrary to an autonomous and democratic sovereignty, the Communal State only recognizes communal partnership and participation for purposes described as "socialist" -

49 National Assembly, 'Report of the Special Commission to Investigate the Conspiracy and Organization of the Coup d'État and Assassination against the Commander and President of the Bolivarian Republic of Venezuela, Hugo Chávez', November 2008, pp. 61-62, at <http://www.asambleanacional.gob.ve/ index2.php?option=com_docman\&task=doc_view\&gid=1268\&Itemid=124>, 3 June 2012.

Bolivarian Republic of Venezuela, Organic Law of People's Power, article 5.8. 
where the collective interests have supremacy over individual interests and the popular consensus on the debate democratic - and its influence is largely restricted to social management in community and communal spaces (...) where they exercise public functions, powers and responsibilities of management, service delivery and execution of works. ${ }^{51}$

Far from being a form of democratic participation, the logic of the communal laws aims to make community organizations a tool in implementing the National Plan designed from the dome of the State, losing their the capacity to influence the decision-making process, inherent to the concept of political participation. Additionally, those organizations whose activity does not meet the directives of the National Plan will tend gradually to disappear or have a marginal existence, unable to influence public policy.

\section{THE BANNER OF ECONOMIC, SOCIAL AND CULTURAL RIGHTS}

There is a widespread view in both home and abroad, that the government of President Chávez has devoted substantial efforts and resources to the satisfaction of social rights of the majority of the population living in poverty.

Undoubtedly, the existence of substantial oil revenues as a result of a never before achieved increases in the price of main export product from Venezuela, has served to partially respond to the needs of most disadvantaged people in areas such as health, education and housing, through the so-called "missions" which have been the main tool of government to address needs in these areas.

However, the missions have not achieved the expected impact on the realization of economic, social and cultural rights largely because these programs are reactive, not incorporated into comprehensive public policies, and participation in them is often subject to political patronage with the ruling party. The missions are not understood as an embodiment of rights, but as a mechanism to meet needs. In the absence of a factor of empowerment of the individual, "missions" recipients are perceived as "users" of a service and not as subjects of rights. Thus, what could be an inclusive policy has degenerated to the development of privileges and discrimination.

According to figures provided by Provea, public social expenditure as a percentage of GDP declined from $21.75 \%$ in 2006 to $18.60 \%$ in 2008 and, consequently, indicators have begun to fall. The President himself admitted in September 2009 that some 2,000 Barrio Adentro modules - the flagship program on health - were abandoned. This is just the result of reduced public expenditure on health as percentage of GDP from 66\% between 2007 and 2008. Similarly, in 2008 public expenditure on housing as a percentage of GDP was $2.33 \%$ versus $3.79 \%$ in $2006^{52}$. Similar cuts are seen in education, so that, according to Arturo Uslar Piertri Foundation, nearly 4 million children

51 'Situación de los derechos humanos y la democracia en Venezuela ante las recientes medidas legislatives', Caracas 2011, at <http://civilisac.files.wordpress.com/2011/02/situacic3b3n-de-ddhh-y-democracia-en-venezuela-ante-recientes-medidas-legislativas1.pdf $>$.

52 PROVEA, Annual report. October 2008-September 2009, Caracas December 2009. 
are out of the school system and $42 \%$ of children who started school in 2000 , had not completed their studies by $2011.5^{33}$ While the budget for fiscal year 2012 continued to experience sharp reductions in social spending, was observed simultaneously an increase of $198 \%$ in defense spending and military equipment. ${ }^{54}$

Additionally, most missions have been affected by the lack of continuity, improvisation, inability to effective management and, sometimes, corruption. Consequently, after years of unfulfilled expectations, the main motivation of social protest is no longer the demands of political freedom but claims for satisfaction of economic, social and cultural rights. Workers rights, social services and right to education are the most common demands of demonstrators. ${ }^{55}$

The Venezuelan Observatory of Social Conflict (SVCO) recorded at least 5338 protests from January to December 2011, out of which $76 \%$ were related to social rights. The demands were directed toward: labor rights, 39\%; housing, 30\%; claims for public safety, rights of persons deprived of liberty, political participation, right to justice $24 \%$; educational requirements $7 \%{ }^{56}$. During the first half of 2012 , the number of protests was reduced by $8 \%$ over the first semester of 2011 , but the proportion of socially motivated expressions of discontent increased: labor rights went up to $41 \%$ and housing to $32 \%{ }^{57}$

\section{PROGRESSIVE ISOLATION AND BREACH OF INTERNATIONAL HUMAN RIGHTS OBLIGATIONS}

Venezuela's failure to comply with regional and international human rights commitments and attempts to isolate the country from the international monitoring is expressed in several forms:

- Refusal or silence to requests for visits from human rights bodies.

- Disrespect of resolutions, judgments and precautionary measures.

- Delays of up to eight years in submitting reports.

- Reluctance to sign and/or ratify new human rights treaties.

53 Fundación Casa Arturo Úslar Pietri, 'Ecarri: “Avanzamos hacia un trágico deslave social”. Fundación Casa Arturo Úslar Pietri presentó Informe anual de educación', at <http://www.casauslarpietri.org/?id=650\&i $\mathrm{d} s=5 \& \bmod =$ conte\&accion $=$ deta $>, 5$ July 2012 (Ecarri: We are moving towards a tragic social mudslide).

54 Transparencia Venezuela, Analysis of the 2012 budget, at <http://www.transparencia.org.ve/ AreasEstrategicas-(2)/Informe-Nuestro-Presupuesto_-2012.aspx>, 5 July 2012.

55 For a comprehensive review of violation to the right to peaceful protest, see Provea, Espacio Público, 'Informe de manifestaciones Públicas 2009', at <http://www.espaciopublico.info/index.php?optio$\mathrm{n}=$ com_docman\&task=cat_view\&gid=43\&dir=DESC\&order $=$ name\&Itemid=99999999\&limi $\mathrm{t}=5$ \&limitstart $=10>, 20$ March 2009.

56 Observatorio Venezolano de Conflictividad Social, 'Tendencias de la conflictividad social en Venezuela', 2011, at <http://observatoriodeconflictos.org.ve/oc/wp-content/uploads/2012/01/Conflictividad-Social-en-Venezuela-en-2011.pdf >.

57 Observatorio Venezolano de Conflictividad Social, 'Tendencias de la conflictividad social en Venezuela. Primer semestre 2012', at <http://observatoriodeconflictos.org.ve/oc/wp-content/uploads/2012/07/Tendencias-de-la-conflictividad-social-en-Venezuela-1er-semestre-2012.pdf>. 
During the last decade no representatives of international or regional bodies for the protection of human rights have been authorized to visit the country. In its recent report on human rights defenders, the Inter American Commission expressed concern for Venezuela's failure to complaint with international commitment: as a rule, the Venezuelan State's position has been to reject the recommendations made by international human rights organizations, on the grounds that such recommendations violate national sovereignty. ${ }^{58}$

Since May 2002, Venezuela has systematically refused visits from the Inter American Commission for Human Rights, based on the so called "conspiracy theory"; according to it, Inter American human rights bodies validated the coup attempt of April 2002. In several occasions the Venezuelan State agent stated that the Commission would not be allowed to visit Venezuela under Santiago Cantón's tenure as Executive Secretary, and Paulo Sergio Pinheiro was the Rapporteur on Venezuela. However, after 2011 election of commissioners and the appointment of a new Rapporteur on Venezuela, new questioning began. The Venezuelan Ambassador to the OAS stated that the new Inter American Commission rapporteur on Venezuela, Felipe González, is a member of the human rights mafia bureaucracy covered by American university of Washington D.C. sponsored by the inter American extreme right wing and added that González is a committed enemy of Bolivarian democracy..$^{59}$

In 2008 a judgment of the Supreme Court had recommended to the National Executive, to denounce the American Convention on Human Rights ${ }^{60}$, which was seconded by several authorities, though did not materialize, and only gained momentum again in April 2012 when the President announced in national radio and TV broadcast, the constitution of the State Council, whose first task would be to study the possibility of withdrawing from the Inter-American Commission on Human Rights.

Only between 2008 and 2011, the Inter-American Court of Human Rights issued a total of 9 sentences ${ }^{61}$, which have not been complied with by Venezuela. The Court

58 Inter-American Commission on Human Rights, 'Second Report on the Situation of Human Rights Defenders in the Americas', 2001, at <http://www.oas.org/en/iachr/defenders/docs/pdf/defenders2011.pdf>, paragraph 450 .

59 See official press release at: <http://www.vtv.gov.ve/index.php/nacionales/76367-chaderton-designacion-de-vocero-chileno-como-relator-de-la-cidh-es-una-provocacion-a-venezuela>, 2 March 2012. Bold added.

60 Supreme Court of Justice, judgment on 18 December 2008, at <http://www.tsj.gov.ve/decisiones/ scon/diciembre/1939-181208-2008-08-1572.html>.

${ }^{61}$ Inter-American Court of Human Rights: Case of Apitz Barbera et al. ("First Court of Administrative Disputes”) v. Venezuela. Preliminary Objection, Merits, Reparations and Costs. Judgment of August 5, 2008. Series C № 182; Case of Ríos et al.v. Venezuela. Preliminary Objections, Merits, Reparations, and Costs. Judgment of January 28, 2009. Series C № 194; Case of Perozo et al. v. Venezuela. Preliminary Objections, Merits, Reparations, and Costs. Judgment of January 28, 2009. Series C № 195; Case of Reverón-Trujillo v. Venezuela. Preliminary Objection, Merits, Reparations, and Costs. Judgment of June 30, 2009. Series C № 197; Case of Barreto-Leiva v. Venezuela. Merits, Reparations and Costs. Judgment of November 17, 2009. Series C № 206; Case of Usón Ramírez v. Venezuela. Preliminary Objection, Merits, Reparations and Costs. Judgment of November 20, 2009. Series C № 207; Case of Chocrón - Chocrón v. Venezuela. Preliminary Objection, Merits, Reparations, and Costs. Judgment 
has emphasized this failure and in four sentences monitoring reports it noted that Venezuela does not have implemented the decisions of the Court. ${ }^{62}$ In addition precautionary measures have been issued in 17 cases $^{63}$; in most of these the State has not adopted the measures necessary for the fulfillment of such requests.

Venezuela has gone from a first phase where the recommendations and rulings were ignored, to a next stage in which its validity is not recognize through the judicial channels, stating that the judgments of the Inter-American Court of Human Rights are "unenforceable", based on a supposed "usurpation of functions" by the international tribunal ${ }^{64}$; to finally reach a third phase in which the judge Maria Lourdes Afiuni, who based a de-

of July 1, 2011. Series C № 227; Case of López Mendoza v. Venezuela. Merits, Reparations, and Costs. Judgment of September 1, 2011. Series C № 233; Case of Barrios Family v. Venezuela. Merits, Reparations and Costs. Judgment of November 24, 2011. Series C № 237.

62 Inter-American Court of Human Rights. Resolutions. Case of Montero Aranguren et al. (Detention Center of Catia) v. Venezuela. Monitoring Compliance with Judgment. Order of the Inter-American Court of Human Rights of November 17,2009; Case of Blanco Romero et al v. Venezuela. Monitoring Compliance with Judgment. Order of the Inter-American Court of Human Rights of July 07, 2009; Case of El Amparo v. Venezuela. Monitoring Compliance with Judgment. Order of the Inter-American Court of Human Rights of February 4, 2010; Case of Apitz-Barbera et al. ("First court of Administrative disputes") v. Venezuela. Monitoring Compliance with Judgment. Order of the Inter-American Court of Human Rights of November 23, 2012.

63 Inter-American Court of Human Rights. Precautionary measures. Matter of Luisiana Ríos et al. regarding Venezuela. Order of the President of the Inter-American Court of Human Rights of June 14, 2007; Case of Guerrero-Gallucci and Martínez-Barrios v. Venezuela. Order of the Inter-American Court of Human Rights of November 29, 2007; Matter of "Globovisión” Television Station regarding Venezuela. Order of the Inter-American Court of Human Rights of November 21, 2007; Matter of "El Nacional" and "Así es la Noticia" Newspapers regarding Venezuela. Order of the Inter-American Court of Human Rights of November 25, 2008; Matter of Carlos Nieto et al. regarding Venezuela. Order of the Inter-American Court of Human Rights of July 03, 2007; Matter of Luis Uzcátegui regarding Venezuela. Order of the Inter-American Court of Human Rights of January 27, 2009; Matter of Liliana Ortega et al. regarding Venezuela. Order of the Inter-American Court of Human Rights of July 09, 2009; Matter of Guerrero Larez regarding Venezuela. Order of the Inter-American Court of Human Rights of November 17, 2009; Matter of Monagas Judicial Confinement Center ("La Pica") regarding Venezuela. Order of the Inter-American Court of Human Rights. November 24, 2009, Matter of Capital El Rodeo I \& El Rodeo II Judicial Confinement Center regarding Venezuela. Order of the Inter-American Court of Human Rights of November 24, 2009; Matter of Yare I and Yare II Capital Region Penitenciary Center regarding Venezuela. Order of the Inter-American Court of Human Rights. November 24, 2009; Matter of the Penitentiary Center of the Central Occidental Region (Uribana Prison) regarding Venezuela. Order of the Inter-American Court of Human Rights of November 24, 2009; Matter of Natera Balboa regarding Venezuela. Order of the Inter-American Court of Human Rights of February 01, 2010; Matter of Eloisa Barrios et al. regarding Venezuela. Order of the Inter-American Court of Human Rights of February 04, 2010; Matter of Belfort Istúriz et al. regarding Venezuela. Order of the Inter-American Court of Human Rights of April 15, 2010; Matter of Centro Penitenciario de Aragua "Cárcel de Tocorón" regarding Venezuela.Order of the Inter-American Court of Human Rights of November 24, 2010; Matter of María Lourdes Afiuni regarding Venezuela. Order of the President of the Inter-American Court of Human Rights of December 10, 2010.

64 Apitz et al. ("Corte Primera de lo Contencioso Administrativo") vs. Venezuela, judgment of 5 August 2008. 
cision on a recommendation by the Working Group on Arbitrary Detention of the United Nations, is herself arbitrarily detained and subjected to trial.

The report prepared by the Office of the United Nations High Commissioner for Human Rights on the occasion of the Universal Periodic Review (UPR) of the Human Rights Council on Venezuela, indicates that the country is overdue in all reports to UN human rights mechanisms for up to eight years. On the occasion of the UPR, Venezuela signed two human rights treaties of the United Nations system. However, no other regional or international treaty has been signed and ratified by Venezuela during the last decade.

In the name of sovereignty the State has expressed a systematic disqualification of regional and international human rights systems, as well as of international non-governmental organizations challenging their research skills and transparency of their decision making process. Since 2000 the Supreme Court had claimed the authority to interpret the Constitution and to use it in a discretional way to declare legal remedies inadmissible ant to disregard rulings by international human rights mechanisms.

\section{FOREIGN POLICY AND HUMAN RIGHTS}

The Venezuela government has adopted a policy of distancing itself from the majority of the international community, in situations where gross and systematic human rights violations have been discussed.

For example, during the 2011 UN General Assembly sessions, the following resolutions were passed:

- A/RES/66/230 (Myanmar): 21 votes against, including Venezuela.

- A/RES/66/176 (Syria): 11 votes against, including Venezuela.

- A/RES/66/175 (Iran): 31 votes against, including Venezuela.

- A/RES/66/174 (North Korea): 16 votes against, including Venezuela.

- A/RES/66/11 (restoring Libya's seat at the Human Rights Council): 4 votes against, including Venezuela.

More recently, in a special UN General Assembly session to discuss the appointment of a Special Envoy (Kofi Annan) to Syria, there were 12 votes against, including Venezuela (A/RES/66/253).

It is worth noting that, in 2006, only three countries abstained in voting for the creation of the Human Rights Council: Iran, Belarus and Venezuela ${ }^{65}$.

In the past, Venezuela played a leading role and urged international and regional initiatives on human rights. Highly qualified jurists had been part and chaired the Commission and Court of Human Rights. A Venezuelan was the first President of the Inter. Other Venezuelans have occupied important positions in the system of protection of United Nations human rights and have had important roles in peace process-

65 UN. Department of Public Information. News and Media Division. New York, at <http://www. un.org/News/Press/docs/2006/ga10449.doc.htm>, 2 March 2012. 
es in Central America, as well as transition processes in African countries. Similarly, Venezuela's foreign policy was characterized by a helping hand to refugees and asylum seekers during the dictatorships that plagued the Southern Cone of the continent in the 70's as well as during armed conflict in Central America in the 80's.

This sustained foreign policy has been reversed on the basis of a distorted concept of sovereignty that understands the international scrutiny of human rights commitments as interference in internal affairs, supposedly based on an alien, westernized and imposed view on the concept human rights.

\section{CONCLUDING REMARKS: DESTROYING THE DEMOCRATIC SYSTEM WITH THE WEAPONS OF DEMOCRACY}

A former president of the Inter-American Court of Human Rights said in a conference recently that the Venezuelan government is using the resources of democracy to destroy democracy. No doubt this is the clearest way to describe the situation in the country. The situation in Venezuela evidence that the plurality of parties and periodic elections are necessary factors, but totally insufficient to declare a regime as democratic.

For over a decade, the current government has made skillful use of democratic institutions, through the subordination of their representatives at the head of the Executive to restrict and to progressively eliminate human rights through the adoption of legislation, the opening of criminal investigations and legislative reforms in order to neutralize dissent and establish a hegemonic power with comprehensive control over the social, political and economic life of citizens.

Behind an appearance of democracy, Venezuela faces a number of major challenges for the recovery of the institutions and the sense of citizenship, in the midst of a situation of impunity and social and legal insecurity, and a productive apparatus severely affected by a inefficient and corrupt administration which recovery will depend on a diminished treasury due to excessive indebtedness.

\section{REFERENCES}

Bolivarian Republic of Venezuela, Organic Law of People's Power, article 5.8.

Boyd A., 'Lista De Tascon: Maisanta Software Explained', at <http://vcrisis.com/index. php?content=pr/200512061532>, 11 March 2011.

Canova González A., La realidad del contencioso administrativo en Venezuela, Caracas 2009.

Canova González A., L.A. Herrera Orellana, K. Anzola Spadaro, ¿Expropiaciones o vías de hecho? La degradación continuada del derecho fundamental de propiedad en la Venezuela actual, Caracas 2009.

Comisión Interamericanade Derechos Humanos, 'Democraciay derechos humanosen Venezuela', 2009, paragraphs 647 to 663, at <http://www.cidh.org/countryrep/Venezuela2009sp/ VE09CAPVSP.htm\#V.B>. 
Criminal Code of Venezuela. Official Gazette No. 5768E, 13 August 2005, at <http://www. fiscalia.gov.ve/leyes/6-CODIGOPENAL.pdf>.

'Designación de vocero de la Cidh es una "provocación” a Venezuela', at <http://www.vtv.gov. ve/index.php/nacionales/76367-chaderton-designacion-de-vocero-chileno-como-relator-de-la-cidh-es-una-provocacion-a-venezuela>, 2 March 2012.

'Espacio Público: Acceso a la información pública en Venezuela', Caracas 2008, at <http://espaciopublico.org/index.php/Biblioteca/doc_download/250-Acceso-a-la-Informacion-publica-en-Venezuela-2008>.

Facsimile of the letter from the President of the Republic to the President of the National Electoral Council, at <http://www.noolvidaremos.com/news/lista-de-tascon-aplicacion-maisanta/>, 11 March 2011.

Flores C., 'Queremos una Asamblea para el soporte de la revolución', at <http://www.el-nacional.com/www/site/p_contenido.php?q=nodo/123846//Cilia-Flores:-Queremos-una-Asamblea-para-el-soporte-de-la-revoluci\%C3\%B3n>.

Fundación Casa Arturo Úslar Pietri, 'Ecarri: "Avanzamos hacia un trágico deslave social". Fundación Casa Arturo Úslar Pietri presentó Informe anual de educación’, at: <http://www. casauslarpietri.org $/$ ?id $=650 \& \mathrm{id} s=5 \& \mathrm{mod}=$ conte\&accion $=\operatorname{deta}>$.

Information provided by human rights NGOs Provea and Espacio Público to the Inter-American Commission for Human Rights. Hearing on Judicialization of Social Protest. 137th Regular Session, 2 November 2009.

Inter-American Commission on Human Rights, Democracy and human rights in Venezuela, OEA/Ser.L/V/II. Doc. 54. Washington, D.C., 30 December 2009.

Inter-American Commission on Human Rights, 'Precautionary Measures 2004', at <http:// www.cidh.org/medidas/2004.eng.htm>, 2 March 2012.

Inter-American Commission on Human Rights, 'Precautionary Measures Granted by the Commission during 2010', PM 380-09 - María Lourdes Afiuni, Venezuela, at <http:// www.cidh.oas.org/medidas/2010.eng.htm>, 20 January 2010.

Inter-American Commission on Human Rights, 'Second Report on the Situation of Human Rights Defenders in the Americas', 2001, at <http://www.oas.org/en/iachr/defenders/ docs/pdf/defenders2011.pdf>.

Inter-American Court of Human Rights: Case of Apitz Barbera et al. ("First Court of Administrative Disputes") v. Venezuela. Preliminary Objection, Merits, Reparations and Costs. Judgment of August 5, 2008. Series C № 182; Case of Ríos et al. v. Venezuela. Preliminary Objections, Merits, Reparations, and Costs. Judgment of January 28, 2009. Series C № 194; Case of Perozo et al. v. Venezuela. Preliminary Objections, Merits, Reparations, and Costs. Judgment of January 28, 2009. Series C № 195; Case of Reverón-Trujillo v. Venezuela. Preliminary Objection, Merits, Reparations, and Costs. Judgment of June 30, 2009. Series C № 197; Case of Barreto-Leiva v. Venezuela. Merits, Reparations and Costs. Judgment of November 17,2009. Series C № 206; Case of Usón Ramírez v. Venezuela. Preliminary Objection, Merits, Reparations and Costs. Judgment of November 20, 2009. Series C № 207; Case of Chocrón - Chocrón v. Venezuela. Preliminary Objection, Merits, Reparations, and Costs. Judgment of July 1, 2011. Series C № 227; Case of López Mendoza v. Venezuela. Merits, Reparations, and Costs. Judgment of September 1, 2011. Series C 
№ 233; Case of Barrios Family v. Venezuela. Merits, Reparations and Costs. Judgment of November 24, 2011. Series C № 237.

Inter-American Court for Human Rights, 'Precautionary Measures IACHR', Res 10 December 2010, at <http://www.ucab.edu.ve/tl_files/CDH/Maria\%20Lourdes\%20Afiuni/Medidas Corte.pdf $>$.

Inter -American Court of Human Rights, Precautionari measures: Matter of Luisiana Ríos et al. regarding Venezuela. Order of the President of the Inter-American Court of Human Rights of June 14, 2007; Case of Guerrero-Gallucci and Martínez-Barrios v. Venezuela. Order of the Inter-American Court of Human Rights of November 29, 2007; Matter of "Globovisión" Television Station regarding Venezuela. Order of the Inter-American Court of Human Rights of November 21, 2007; Matter of "El Nacional” and "Así es la Noticia” Newspapers regarding Venezuela. Order of the Inter-American Court of Human Rights of November 25, 2008; Matter of Carlos Nieto et al. regarding Venezuela. Order of the Inter-American Court of Human Rights of July 03, 2007; Matter of Luis Uzcátegui regarding Venezuela. Order of the Inter-American Court of Human Rights of January 27, 2009; Matter of Liliana Ortega et al. regarding Venezuela. Order of the Inter-American Court of Human Rights of July 09, 2009; Matter of Guerrero Larez regarding Venezuela. Order of the Inter-American Court of Human Rights of November 17, 2009; Matter of Monagas Judicial Confinement Center ("La Pica") regarding Venezuela. Order of the Inter-American Court of Human Rights. November 24, 2009, Matter of Capital El Rodeo I \& El Rodeo II Judicial Confinement Center regarding Venezuela. Order of the Inter-American Court of Human Rights of November 24, 2009; Matter of Yare I and Yare II Capital Region Penitenciary Center regarding Venezuela. Order of the Inter-American Court of Human Rights. November 24, 2009; Matter of the Penitentiary Center of the Central Occidental Region (Uribana Prison) regarding Venezuela. Order of the Inter-American Court of Human Rights of November 24, 2009; Matter of Natera Balboa regarding Venezuela. Order of the Inter-American Court of Human Rights of February 01, 2010; Matter of Eloisa Barrios et al. regarding Venezuela. Order of the Inter-American Court of Human Rights of February 04, 2010; Matter of Belfort Istúriz et al. regarding Venezuela. Order of the Inter-American Court of Human Rights of April 15, 2010; Matter of Centro Penitenciario de Aragua "Cárcel de Tocorón" regarding Venezuela.Order of the Inter-American Court of Human Rights of November 24, 2010; Matter of María Lourdes Afiuni regarding Venezuela. Order of the President of the Inter-American Court of Human Rights of December 10, 2010.

Inter-American Court of Human Rights. Resolutions. Case of Montero Aranguren et al. (Detention Center of Catia) v. Venezuela. Monitoring Compliance with Judgment. Order of the Inter-American Court of Human Rights of November 17, 2009; Case of Blanco Romero et al v. Venezuela. Monitoring Compliance with Judgment. Order of the Inter-American Court of Human Rights of July 07, 2009; Case of El Amparo v. Venezuela. Monitoring Compliance with Judgment. Order of the Inter-American Court of Human Rights of February 4, 2010; Case of Apitz-Barbera et al. ("First court of Administrative disputes”) v. Venezuela. Monitoring Compliance with Judgment. Order of the Inter-American Court of Human Rights of November 23, 2012. 
Interview to Rocío San Miguel Correo del Caroní, at <http://informe21.com/rocio-san-miguel/rocio-san-miguel-\%E2\% 80\%9Caqui-hay-politica-acelerada-discriminacion $\% \mathrm{E} 2 \% 80 \% 9 \mathrm{D}>$.

GacetaOficial, 23December 2010, at < http://www.tsj.gov.ve/gaceta_ext/Diciembre/23122010/E-23122010-3043.pdf\#page=1>, 6 March 2010.

Morales L.E., 'La division de poderes debilita al Estado', El Nacional (Caracas), 5 December 2009, at <http://www.el-nacional.com/www/site/p_contenido.php?q=nodo/111866/Nacional/Luisa-Estela-Morales:-La-divisi\%C3\%B3n-de-poderes-debilita-al-Estado>, 19 April 2010.

Morales L.E., 'La división de poderes debilita al Estado'>, at <http://www.eluniversal. com/2009/12/05/pol_art_morales:-la-divisio_1683109.shtml>, 17 June 2013.

National Assembly, 'Report of the Special Commission to Investigate the Conspiracy and Organization of the Coup d'État and Assassination against the Commander and President of the Bolivarian Republic of Venezuela, Hugo Chávez', November 2008, at <http://www.asambleanacional.gob.ve/index2.php?option $=$ com_docman \&task=doc_ view\&gid=1268\&Itemid=124>, 3 June 2012.

'Observatorio de la propiedad (Property Watch)', at <http://cedice.org.ve/?p=6244>.

Observatorio Venezolano de Conflictividad Social, 'Tendencias de la conflictividad social en Venezuela', 2011, at <http://observatoriodeconflictos.org.ve/oc/wp-content/ uploads/2012/01/Conflictividad-Social-en-Venezuela-en-2011.pdf>.

Observatorio Venezolano de Conflictividad Social, 'Tendencias de la conflictividad social en Venezuela. Primer semestre 2012', at <http://observatoriodeconflictos.org.ve/oc/wp-content/uploads/2012/07/Tendencias-de-la-conflictividad-social-en-Venezuela-1 er-semestre-2012.pdf>.

PROVEA, Annual report. October 2008-September 2009, Caracas December 2009.

Provea, Espacio Público, 'Informe de manifestaciones Públicas 2009', at <http://www.espaciopublico.info/index.php?option $=$ com_docman\&task $=$ cat_view\&gid $=43 \&$ dir $=$ DESC\&ord er=name\&Itemid=99999999\&limit=5\&limitstart=10>, 20 March 2009.

Situación de los Derechos Humanos en Venezuela, Informe Anual octubre 1988 / Septiembre 1989, Programa Venezolano de Educación - Acción en Derechos Humanos (PROVEA), Caracas 1989.

'Situación de los derechos humanos y la democracia en Venezuela ante las recientes medidas legislatives', Caracas 2011, at <http://civilisac.files.wordpress.com/2011/02/situacic3b3n-de-ddhh-y-democracia-en-venezuela-ante-recientes-medidas-legislativas1.pdf $>$.

Supreme Court. Constitutional Chamber, Decision № 12-0219, 14 February 2012, at <http:// www.tsj.gov.ve/decisiones/scon/Febrero/66-14212-2012-12-0219.html>.

Supreme Court. Constitutional Chamber, Decision № 145, 23 February 2012, at <http://www. tsj.gov.ve/decisiones/scon/Febrero/145-23212-2012-12-0219.html>.

Supreme Court of Justice, Judgment on 18 December 2008, at <http://www.tsj.gov.ve/decisiones/scon/diciembre/1939-181208-2008-08-1572.html>.

'The price of political opposition: Evidences from Venezuela's Maisanta', 2009, at <http://frrodriguez.web.wesleyan.edu/docs/working_papers/maisanta_april2009_final.pdf $>$. 
Transparencia Venezuela, Analysis of the 2012 budget, at <http://www.transparencia.org.ve/ AreasEstrategicas-(2)/Informe-Nuestro-Presupuesto_-2012.aspx $>$.

UN. Department of Public Information News and Media Division New York, at <http://www. un.org/News/Press/docs/2006/ga10449.doc.htm>.

'UN experts alarmed at continued detention of Venezuelan Judge Afiuni', United Nation Press Release, 27 December 2011, at <http://www.ohchr.org/EN/NewsEvents/Pages/ DisplayNews.aspx ?NewsID $=11745 \&$ LangID $=\mathrm{E}>$.

'UN experts: President Chávez deals new blow to independence of judges and lawyers in Venezuela, United Nation Press Release, 16 December 2009, at <http://www.ohchr.org/ EN/NewsEvents/Pages/DisplayNews.aspx?NewsID=9677\&LangID=E >.

UN Human Rights Council, 'Opinions adopted by the Working Group on Arbitrary Detention', 2 March 2010, 'OPINION № 10/2009', p. 307, at <http://www2.ohchr.org/english/bodies/hrcouncil/docs/13session/A-HRC-13-30-Add1.pdf $>$.

Ligia Bolívar O., degree in Sociology at the Catholic University Andres Bello, Caracas (1980). Human Rights Specialist at the Faculty of Law and Political Sciences of the Central University of Venezuela, Caracas (1995-1999). Since 1999, director of the Center for Human Rights, Faculty of Law, Catholic University Andres Bello, Caracas. 